\title{
Does internal corporate governance mechanism control firm risk? Evidence from Indonesia's three high-risk sectors
}

\author{
Saarce Elsye Hatane, Stellania Supangat, Josua Tarigan, Ferry」tie \\ Corporate Governance \\ ISSN: $1472-0701$ \\ Bntefrcatidipnadte: 2 December 2019 \\ Standard \\ Serial

\section{Alastriact} \\ Purpose \\ This study aims to examine the control of corporate governance \\ towards firm risks for a sample of Indonesian firms in agriculture, \\ mining and property industries. This study highlights the impact of \\ four indicators of internal mechanism of corporate governance, i.e. \\ board size, board independence, board gender and board \\ ownership, on three measurements of firm risks, i.e. total risk, asset \\ return risk and idiosyncratic risk.
}

\section{Design/methodology/approach}

Panel data analysis is conducted using a sample of 62 companies of agriculture, mining and property industries listed in Indonesia Stock Exchange from 2013 to 2017. Pooled ordinary least square with hetero-corrected is the statistical approach conducted to test the hypotheses.

\section{Findings}

The result indicates that board size and board gender insignificantly influence firm risks. While board independence gives varied impacts towards firm risks, it gives positive influence towards total asset return risk, insignificant towards idiosyncratic risk and negative towards total risk. Other interesting results are found in board ownership that has insignificant influence on asset return risk and negative influence on idiosyncratic and total risk.

\section{Research limitations/implications}

Firms should incorporate corporate governance, especially the impactful roles of board independence and board ownership as they serve as tools in reducing firm risk. Moreover, investors may have a better understanding of corporate governance and factors that are influencing firm risks. Therefore, this studv can assist them 
various types of risks facing the company. Total risk measures both the internal and external risks, while asset return risk gives another perspective using overall market perception about the equity and assets of the company. Finally, this study also measures internal risk, which is the only risk that can be controlled and minimised by the board of the company.

\section{Keywords}

\section{Corporate governance Firm risks Idiosyncratic risk \\ Asset return risk Total risk}

\section{Citation}

Hatane, S., Supangat, S., Tarigan,.J. and Jie,_F. (2019), "Does internal corporate governance mechanism control firm risk? Evidence from Indonesia's three high-risk sectors", Corporate Governance, Vol. 19 No. 6, pp. 1362-1376. https://doi.org/10.1108/CG-02-2019-0071

Download as.RIS

Publisher: Emerald Publishing Limited

Copyright (c) 2019, Emerald Publishing Limited

Please note you might not have access to this content

You may be able to access this content by login via Shibboleth, Open Athens or with your Emerald account.

Login $\quad 8$

To rent this content from Deepdyve, please click the button.

\section{Rent from Deepdyve}

If you would like to contact us about accessing this content, click the button and fill out the form.

\section{Contact us}

$\begin{array}{ll}\text { Services } & \text { About } \\ \text { Authors } & \text { About Emerald } \\ \text { Editors } & \text { Working for Emerald } \\ \text { Librarians } & \text { Contact us } \\ \text { Researchers } & \text { Publication Sitemap } \\ \text { Reviewers } & \end{array}$

Policies and information

Legal

Editorial policy \& originality

guidelines

Site policies

Modern Slavery Act 